\title{
Lactose Inducible Fermentation in Escherichia coli for Improved Production of Recombinant Urate Oxidase: Optimization by Statistical Experimental Designs
}

Research

Keywords:

Posted Date: October 28th, 2020

DOl: https://doi.org/10.21203/rs.3.rs-93296/v2

License: (1) This work is licensed under a Creative Commons Attribution 4.0 International License. Read Full License 


\section{Abstract}

The authors have requested that this preprint be withdrawn due to erroneous posting.

\section{Full Text}

The authors have withdrawn this preprint from Research Square. 